\title{
Simbolika sablje u Yoshikawinom romanu Musashi
}

\section{Abstract: The Symbolism of the Sword in Yoshikawa's Musashi}

In his masterpiece Musashi (1935), the author Eiji Yoshikawa depicts the birth of an ingenious swordsman and his spiritual evolution towards the final awakening (satori). While constructing the character of Miyamoto Musashi, Yoshikawa uses the elements of Zen Buddhist philosophy and describes Musashi's progress on his way of enlightenment through a series of direct personal insights (kensho) that precede satori. The paper aims to discuss and analyze Musashi's use of different types of swords that metaphorically suggest his personal and spiritual transformation from an untamed and uncultivated person to his ultimate enlightenment. Initially, Musashi fights with a wooden sword (bokken), which symbolizes his animalistic, rampant nature. As he progresses on the way of enlightenment, Musashi embraces the steel sword (katana), though he still uses bokken at times. The struggle between his wild and civilized nature culminates at the moment of kensho, when he starts fighting with two steel swords, which represents a true evolution that elevates him to the level of the Nietzschean Übermensch. The final birth of Musashi as a Rinzaian "man of no rank" is the moment of his ultimate awakening, symbolically depicted when he again reaches for the wooden sword. This act unmasks his true Buddhist nature, thus suggesting Musashi's return to "oneself."

Keywords: Eiji Yoshikawa, Japanese literature, Musashi, swordsmanship, Zen Buddhism

\section{Uvod}

\subsection{Osoba i lik Miyamotoa Musashija}


Eiji Yoshikawa (1892-1962) jedan je od najpoznatijih i najcjenjenijih japanskih pisaca povijesnih romana. Svoje kapitalno djelo pod nazivom Musashi objavljuje kao seriju pripovijetki u japanskim nacionalnim dnevnim novinama Asahi Shimbun u razdoblju od 1935. do 1939. godine. U djelu opisuje život jednog od najpoznatijih japanskih mačevalaca svih vremena, Miymotoa Musashija, stavljajući fabulu u povijesni i običajni kontekst feudalnog Japana. Kao primarni izvor u radu korišten je prijevod Dragana Milenkovića s japanskoga na srpski jezik iz 1988. godine.

Miyamoto Musashi (1584-1645) povijesna je osoba. Živio je na prijelazu iz 16. u 17. stoljeće, a u povijest je ušao kao legenda mačevalačke vještine. Karakterizirale su ga različite inovacije u borbi sabljom, primjerice, ravnopravna upotreba dviju sablji (duga - katana i kratka - wakizashi) tijekom borbe, što je bilo suprotno svim do tada poznatim načinima mačevanja, jer su samuraji u borbi koristili samo dugu sablju koju su držali s obje ruke. To mu je, uz neke druge originalne strateške manevre, omogućavalo ravnopravnu borbu s više protivnika po čemu je postao nadaleko poznat. Poznat je podatak da je sudjelovao u šezdesetak borbi i da nikada nije bio poražen. Iza sebe je ostavio pisani trag pod nazivom Go Rin No Sho (Pet krugova ili Pet prstenova), djelo u kojem je opisao svoje viđenje strategije borbe i ratovanja te tehniku borbe sabljom koju je osmislio i usavršio. Također, krasile su ga i različite umjetničke sklonosti kao što je drvorez, kaligrafija i slikanje. Neki njegovi radovi sačuvani su i izloženi u nekoliko japanskih muzeja.

Lik Miyamotoa Musashija Yoshikawa razrađuje postavljajući ga u različite životne okolnosti koje upravljaju njegovim duhovnim razvojem. Ono što razlikuje ovaj roman od prethodnih dramskih i proznih djela koja su se bavila osobom Miymotoa Musashija, prikazujući ga kao nacionalnog junaka i najvećeg samuraja svih vremena, jest Yoshikawin pokušaj da samog Musashija prikaže ne samo kao mačevalačkog genija i osobenjaka već kao običnog čovjeka sa svim uobičajenim Ijudskim vrlinama i manama: „Tek je pisac Eiđi Jošikava ... pokušao da Musašija prikaže kao ljudsko biće ... Jošikava je stvorio Musašija koji ima tipične ljudske slabosti: zaljubljuje se, stidljiv je, ume čak i da pobegne od dvoboja, a dozvoljava i da s njim ponekad arogantno postupa budistički kaluđer Takuan“ (Milenković 172-73).

\subsection{Društveno-povijesno-religijski kontekst}


Kako ističe Milenković, samuraji, drevni japanski ratnici, bili su pripadnici ratničkog staleža (bushị ${ }^{11]}$ ) koji je imao poseban društveni položaj u feudalnom Japanu. Tadašnji japanski velikaši brzo su shvatili potrebu stvaranja profesionalne vojske sastavljene od izvrsno uvježbanih ratnika, vještih u borbi sabljom, potpuno posvećenih služenju svog gospodara - feudalca. Sâm naziv samuraj potječe od japanskog glagola saburau (samurau), što znači služiti, odnosno čuvati (nekoga). Feudalni gospodar smatran je jednakovrijednim roditelju ili čak božanstvu. $U$ tom se kontekstu od samuraja zahtijevala bezuvjetna predanost gospodaru kojemu služi, čak i pod cijenu vlastitog života. S druge strane, samuraji su uživali visok položaj u društvu, koji se očitovao kako u prihodima i posjedima (npr. vlastite kuće) tako i u njihovu odnosu prema pripadnicima drugih staleža - trgovcima, zanatlijama, seljacima i drugima - koji je često bio ekstremno agresivan, rezultirajući ponekad i smrću člana nižeg staleža, bez pravnih ili drugih posljedica po samuraje. Ipak, način ponašanja i življenja samurajskog staleža bio je propisan posebnim etičkim kodeksom koji se naziva bushi-do ili put ratnika, što je samuraja stavljalo u potpuno definiran i poželjan položaj u okviru tadašnje društvene hijerarhije (Milenković 139-40).

Radnja romana Musashi smještena je u vrijeme bitke na Sekigahari (središnji dio Japana) koja se odigrala 1600. godine te u razdoblje od narednih dvanaest godina. Bitka je predstavljala prekretnicu u povijesti Japana koji je do tada bio u višestoljetnom kaosu brojnih građanskih ratova i međusobnih sukoba feudalnih vladara (Frederik i Random 73). U bici kod Sekigahare, lejasu Tokugawa odnosi pobjedu nad Ishidom Mitsunarijem te nakon tri godine od cara dobiva titulu shoguna (titula korištena u feudalnom Japanu koja označava vrhovnog zapovjednika japanske carske vojske, koji je često imao veće ovlasti i od samog cara). Tokugawa centralizira vlast i uvodi politiku „čvrste ruke“ uslijed čega prestaju ratovi i započinje duži period mira i prosperiteta. Prestankom ratova smanjena je potreba za plaćeničkom vojskom i velik broj samuraja ostaje bez službe. Tome doprinosi i propast velikog broja feuda koji su u bici kod Sekigahare bili dio gubitničke Mitsunarijeve armade te veliki materijalni nameti koje su feudalci morali plaćati novom shogunu, zbog čega, ističe Milenković, nisu mogli uzdržavati veliki broj samuraja (141). Samuraji koji su preko noći ostali bez gospodara kojem bi služili počeli su lutati Japanom. Nazivali su se roninima ili lutajućim samurajima, a glavni im je cilj bio izučavanje i usavršavanje vještine borbe sabljom uslijed čega je dolazilo do čestih dvoboja. 
Filozofsko-religijski utjecaj na samurajski kodeks opisuje Inazo Nitobe u svojem kapitalnom djelu Bushido: kodeks samuraja. Kao krucijalne, on izdvaja tri stupa na kojima počiva samurajski etički kodeks: shintoizam, konfucionizam i zen-budizam (20-26). Temeljno načelo služenja gospodara bushido crpi iz shintoizma, japanske autohtone religije koja načelo poštovanja i odanosti prema gospodaru i domovini razvija do ekstrema. Paradigma ovog ekstrema su kamikaze, piloti samoubojice, primjer iz novije japanske povijesti. Konfucionizam pak propisuje moralne vrijednosti koje harmoniziraju odnose između gospodara (onog koji upravlja) i podanika (onog kojim se upravlja) na način koji samurajima omogućava obavljanje dužnosti prema gospodaru tako da se ne osjećaju poniženima, već časnim, hrabrim i istinoljubivim pripadnicima svog staleža. Konačno, utjecaj zena na konstrukciju bushidoa određuje ponašanje samuraja u bilo kojoj prilici (bilo u ratu bilo u miru). To se prvenstveno odnosi na stoički odnos samuraja prema svakoj vrsti neugode, gledanje smrti „ravno u oči“ te izdizanje iznad intelekta, koji predstavlja smetnju ne samo u borbi na život ili smrt već i u svakodnevici. Dakako, treba istaknuti kako ova tri stupa bushidoa ne interferiraju međusobno već su komplementarni, stvarajući sustav koji je, s jedne strane bio dovoljno pouzdan da bi omogućio stabilnost hijerarhijske strukture društva (unatoč stalnim političkim previranjima i ratnim djelovanjima), a s druge strane dovoljno fleksibilan da bi podnosio, s gledišta japanske tradicije, devijantne pojave uzrokovane različitim trendovima koji su nastajali tijekom vremena.

\subsection{Uloga sablje u osobnom i kolektivnom poimanju samuraja}

Na spomen riječi samuraj, većina ljudi gotovo trenutačno stvara sliku ratnika sa sabljom u rukama. Ta predodžba predstavlja iskonsku povezanost ovih pojmova i doista je utemeljena na suštinskoj isprepletenosti samuraja i njegove sablje. Verbalizaciju ovog koncepta najčešće možemo čuti u legendarnoj izjavi: „Sablja je duša samuraja!“. Objašnjenje ove naizgled apsurdne izjave možemo potražiti u Suzukijevoj raspravi o zenu i samurajima:

Kad se ... [sablja] ne odvaja od čovjeka ona je produžetak njegovih ruku i u skladu s tim, dio njegovog tijela. Osim toga, tijelo i um ne razdvajaju se, kao što je slučaj pri razmišljanju. Um i tijelo u savršenom su jedinstvu, u kojem ih ne ometaju ni razum ni emocije. Čak se poništava i razlika između subjekta i objekta. (82-83) 
Ovakvo poimanje sablje podrazumijevalo je postizanje savršenstva u rukovanju njome, što je bila prava opsesija samurajskog staleža, pri čemu je borba sabljom postajala umjetnost i razlikovala se od pukog „mahanja“ oružjem tek onda kad je samuraj postigao stanje u kojem je bio „oslobođen svih ovozemaljskih briga“ (Stori 50). Nadalje, shintoistička mitologija govori o sablji kao jednoj od tri dragocjenosti (uz ogledalo i dragulj) koje je unuk božice Sunca Amaterasu, Ninigi, predao svom descendentu, prvome japanskom caru, a koje se i danas smatraju imperijalnim simbolima Japana (Roberts 89). U tom kontekstu, gdje je samurajska lojalnost gospodaru i domovini conditio sine qua non, ne iznenađuje iskonska povezanost samurajskog staleža, kao kolektivne svijesti, i sablje kao simbola samurajske duše.

Utjecaj filozofije zena na borilačke vještine i samuraje tadašnjeg vremena bio je posebno izražen kroz neprestano usavršavanje vještine borbe sabljom. Bio je to „zapravo svakodnevni rad bez (ikakvog očekivanja) plaće“ (Vertovšek 135-36). Yoshikawa upravo taj motiv koristi u izgradnji lika Miyamotoa Musashija, koji od seoskog „mangupa“ preko lutajućeg samuraja (ronina) sazrijeva do mačevalačkog genija koji svoje konačno prosvjetljenje (satori) doživljava na samom kraju romana, neposredno prije ključnog dvoboja s glavnim oponentom Sasakijem Kojiroom. Taj Musashijev put k satoriju Yoshikawa vješto podcrtava upravo sabljom, kao oličenjem samurajske duše. Glavna je teza rada simbolika korištenja različitih tipova sablji tijekom Musashijeva napredovanja na putu (do ) prosvjetljenja pri čemu protagonist počinje i završava korištenjem drvene sablje i na taj način ilustrira svoju buddhinsku prirodu, odnosno povratak „k sebi. “

\section{Simbolika sablje}

\subsection{Drvena sablja (bokken), odnosno ovladavanje životinjskim nagonima}

Musashija u romanu prvi put susrećemo pod imenom Shimmen Takezo, netom nakon izgubljene bitke na Sekigahari, kako leži izranjen na bojnom polju s prijateljem iz djetinjstva Honidenom Matachijem. Mladići su se igrom slučaja uspjeli skloniti u kuću dviju žena, majke Oko i kćeri Akemi, koje su ih skrivale od patrola pobjedničke vojske, hranile i njegovale. Jednom prigodom, Oko 
daruje Takezou (Musashi) drvenu sablju s kojom ovaj trenutno osjeti duboku povezanost: „U trenutku ona se vrati sa skoro metar i pol dugim drvenim mačem [sabljom] od crne hrastovine. Takezo pođe da ga doda Matahaćiju, ali težina, zakrivljenost, savršena ravnoteža oružja koje je osećao u rukama toliko ga oduševi da je morao da zastane“ (Jošikava 1: 28).

Drvena sablja ili bokken često je korištena za uvježbavanje tehnike mačevanja zato što je, za razliku od čeličnih sablji, ipak bila manje opasna, pa samim time pogodna za početnike. Također, imala je i drugu svrhu - bila je namijenjena razvijanju filozofskog pristupa životu koji suprimira agresiju (Vertovšek 126). Ipak, u rukama istinskog majstora drvena je sablja bila gotovo jednako učinkovita kao i katana, što Yoshikawa vrlo realistično opisuje na nekoliko različitih mjesta tijekom razrade fabule romana; drvena je sablja u pravim rukama lomila kosti i trgala udove (Jošikava 1: 40; 159). Drvo, kao lako dostupan prirodni materijal, bilo je idealno za izradu ovakvog oružja. Također, drvo je i materijal vrlo rado korišten u kiparstvu zbog toga „što ima ukočenu strukturu. Ona mu pomaže da donese motive koje karakterizira sabrano ili uzvišeno držanje i dade takav izraz kojemu je osnova zaustavljanje crta, ploha volumena u čvrstu, nepokolebljivu cjelinu kipa“ (Peić 97). Dakle, drvo je medij koji se svojom strukturom odlikuje, s jedne strane, nepokretnošću i čvrstoćom što predstavlja analogiju uobičajene percepcije materijalne stvarnosti, a s druge strane, svojom mekoćom i podatnošću omogućuje umjetniku, ponajviše od svih ostalih prirodnih materijala (kamen, bronca, terakota...), eksprimirati kreaciju koja u mnogim slučajevima stremi k transcendentnom. Ontologijski, drvo simbolizira prazninu (ku, sunyata) ${ }^{[2]}$ koja je istovjetna nediferenciranoj svijesti te je stoga sveprisutna i totipotentna, odnosno „ima mogućnost svake stvari“ (Ščerbatski 37). Snaga ove totipotentnosti praznine u Musashijevu slučaju leži u njezinoj sposobnosti upogonjenja evolucije životinjske prirode do ljudskog bića, a potom i do nadčovjeka, genija i konačno do probuđenoga (Buddhe). U tom je smislu upravo bokken poslužio Yoshikawi kao metafora izvorišnog oblika (bitka) koji stremi k prosvjetljenju stupajući na put ratnika. Pisac, kroz lik zen-budističkog svećenika Takuana Sohoa, progovara o Musashiju, tada još pod imenom Takezo, kao o odmetniku, simbolu kaosa, osobi bez zdravog razuma, čudovištu kojeg se svi boje, osobi kojom vladaju životinjski nagoni. S ovog gledišta, upravo je Takuan jedina uporišna točka koja može Takezoa oplemeniti i od njega napraviti ljudsko biće. Nakon što ga navede da se 
dobrovoljno preda vlastima i sveže ga za veliko drvo, Takuan se obraća Takezou sljedećim riječima:

Pre nego što se pretvoriš u osušeno meso, Takezo, bilo bi dobro da osmotriš malo svet oko sebe. Gledaj svet u kome žive ljudska bića i pokušaj da promeniš svoj sebični način mišljenja ... lako si rođen kao ljudsko biće više sličiš na zver, medveda, vuka. Zar je tako lep i snažan mladić kao ti morao da dočeka ovakav kraj pre nego što stvarno postane čovek? Kakva šteta! (Jošikava 1: 110-

Nakon što ga navede na dobrovoljnu predaju vlastima, Takuan odvodi Takezoa u dvorac velikaša Terumasua Ikede, gdje ga zatvara u prostoriju u kojoj ovaj provodi tri godine čitajući literaturu o vještini ratovanja, zenu i povijesti, s jednim jedinim ciljem - uljudbe: „Budi u ovoj sobi kao da je utroba tvoje majke i pripremaj se da se ponovo rodiš. Ako je promatraš samo očima, videćeš mračnu ćeliju. Ali, pogledaj bolje, gledaj je dušom, i ova soba će za tebe postati izvor prosvetljenja, fontana znanja. Ti ćeš sam odlučiti da li je ovo soba svetla ili soba tame“ (Jošikava 1: 134).

Prije zatvaranja, Takezo dobiva na poklon simbole svog potencijalnog života: novi kimono, lepezu, malo bijelog papira te dvije samurajske sablje - dugu i kratku. Ovaj trenutak nagovješćuje uvid ( kensho) koji se tek treba dogoditi nekad tijekom Musashijeva boravka u „sobi znanja“, što parcijalno koincidira s ničeanskom preobrazbom deve u lava (Nietzsche 87-88) ${ }^{[3]}$ čime se Musashi treba osloboditi djelovanja kojim dominiraju životinjski nagoni i početi djelovati kao njihov gospodar.

Nakon puštanja iz „sobe znanja“, velikaš Ikeda i Takuan nadjenu Takezou novo ime -Miyamoto Musashi, što je bio simbol njegova preporoda, odnosno uljudbe, te je sada mogao krenuti u „novi život, život discipline i usavršavanja u borbenim veštinama“ (Jošikava 1: 136). Naznake Musashijeve ljudskosti Yoshikawa daje nekoliko puta i prije ovog trenutka. Prva nedvojbena naznaka ljudskosti događa se u trenutku kad mu, svezanom za drvo, Takuan priopći da će ga još jednu noć ostaviti u tom stanju, a nakon toga dekapitirati. U očaju mladić krikne: „Ne želim da umrem! ... Želim da živim! Želim da sve pokušam ponovo. Sad, odmah!“ (Jošikava 1: 118). Ovakva reakcija u potpunosti je ljudska i utemeljena na bazičnoj emociji straha. Gruden ističe kako je strah „najneugodniji osjećaj i na nj nema privikavanja“ (37). Svakako, taj strah od smrti kojeg 
Musashi afektirano eksprimira predstavlja, zapravo, strah od dezintegracije vlastite ličnosti što je razotkriveno njegovim vapajem za još jednom prilikom. Upravo ta želja dijeli ljudski strah u Musashiju od onog životinjskoga. Sljedeći bljesak Musashijeve ljudskosti zbiva se u trenutku pada s drveta u zagrljaju s djevojkom Otsu koja ga je, motivirana bezuvjetnom ljubavlju, odlučila osloboditi s drveta, čak i po cijenu vlastitog života. Time se nagovještava nadolazeći osjećaj ljubavi muškarca prema ženi s kojim se Musashi tek mora suočiti tijekom svojega daljnjeg puta prosvjetljenja. Osim ljubavnih osjećaja, Musashi osjeća i stid što je svojim ranijim, nepromišljenim postupcima „okaljao ime svojih predaka“ (Jošikava 1: 132) čime dodatno potvrđuje svoju ljudsku stranu. Konačno, četvrta naznaka Musashijeve ljudskosti, definitivna potvrda njegove preobrazbe nakon tri godine provedene u „sobi znanja“, ističe njegovu novostečenu posvećenost tradicijskim vrijednostima jer konačno duboko osjeća da duguje „|judima ovog kraja poštovanje prema duhovima predaka“ (Jošikava 1: 135).

Osvješćivanje ovog tipično ljudskog stava pripadnosti (ljudima, običajima i mjestu s kojeg potječe) jest conditio sine qua non, odnosno mentalna platforma neophodna za daljnju Musashijevu preobrazbu od običnog, sada uljuđenog čovjeka, u mačevalačkog genija, odnosno ničeanskog nadčovjeka, koji bi ostvario potpunu slobodu djelujući na putu sablje.

\subsection{Put sablje - niz kenshoa}

Vrlo brzo nakon izlaska iz „sobe znanja“, slijedi novi kensho, naime, Musashi osvješćuje put sablje kao svoj konačni životni odabir:

Srce mu je govorilo da istom brzinom kao i Ocu on treba da potrči u suprotnom pravcu i pobegne od nje. Ono što ga je još držalo na mostu bilo je, međutim, njegovo telo. Njega kao da je kočila zadata reč ... On izvadi kratak mač i poče brzo da urezuje nešto u ogradi ... Na ogradi je bila poruka urezana Musašijevim bodežom: 'Oprosti mi. Oprosti mi' ... 'Sada ostaje samo mač, ovaj mač, jedina stvar na svetu na koju mogu da se oslonim. Živeću postupajući po tom pravilu. Mač ću smatrati svojom dušom i postajati savršeniji dok učim kako da ga bolje upotrebim' ... put koji ga je vodio u budućnost, nepoznati put kojim svi ljudi, svaki za sebe, moraju da prođu. (Jošikava 1: 141) 
Ovakvo konstruiranje mentalne platforme Musashijeva promišljanja, koristeći ispravan uvid, ispravno razumijevanje i ispravno djelovanje kao neosporne elemente puta oslobođenja osmerostrukom stazom (Bodhi 14-111) potpuno je u skladu s pretpostavljenim dosegom satorija. Ispravno djelovanje na putu sablje za Musashija znači povlačenje u izolaciju planina gdje bi u samoći kreirao i uvježbavao različite tehnike borbe sabljom, ali i lutanje zemljom s ciljem traženja dostojnih protivnika s kojima bi se ogledao u dvobojima (Jošikava 1: 158-99). U dvobojima, Musashijev kriterij izbora protivnika bio je isključivo motiviran učenjem. Naravno, ovo je učenje uvijek bio ples na granici života i smrti i svaki je novi dvoboj mogao završiti fatalno. Tim više, zadivljuje lakoća kojom Musashi isključuje motiv osobnog obračuna s nekom osobom ili likovanja nakon pobjede u dvobojima. On prianja uz potencijalnog učitelja neovisno o njegovu identitetu, motiviran jedino napretkom na putu (do): „Kad se vratio u sobu, Musaši se ponovo zamisli nad onim što mu je govorio starac u Hozoinu. Uvek kada bi nekoga pobedio, on bi ga već sledećeg trenutka zaboravljao, kao da nije ni postojao. Ali, kada bi neko u njemu ostavio ovakvo osećanje poraza, kasnije je neprekidno mislio o njemu“ (Jošikava 1: 206).

Kako ističe Sumedho, u Buddhinu učenju o četiri plemenite istine, smatra se da je uzrok patnje pogrešno prianjanje uzrokovano neznanjem, odnosno poistovjećivanje sa željom, tj. žudnja. Tek nevezanost uz želju lišava patnje. S obzirom da intelektualiziranje, svojstveno diskurzivnom umu, samo i uvijek vraća osobu nazad žudnji, preporuča se ,jednostavno otpuštanje“ bez ikakve analize i pokušaja verbaliziranja problema. Ustrajnost u smislu uvježbavanja ovakvog pristupa konačno dovodi do konstantnog stanja nevezanosti (Sumedo 40-44). U tom kontekstu, Musashi je uspijevao održavati dostatnu razinu nevezanosti koja ga je konstantno motivirala za daljnje učenje, odnosno napredak na putu prosvjetljenja.

Povijesnog Musashija povezivalo se s različitim vrstama ekstremnog ponašanja koja nisu bila u duhu bushidoa. lako Musashi gotovo nikad ne odbija priliku učiti iz dvoboja, često odbija borbu i daje se u bijeg ako procijeni da je ista besmislena, odnosno ukoliko ni on ni njegov protivnik neće ništa naučiti. Takvo mu ponašanje vrlo brzo pribavlja epitet kukavice. Drugi ekstrem po kojem je povijesni Musashi postao poznat već za života bili su dvoboji s većim brojem protivnika. Yoshikawa detaljno opisuje ovakve dvoboje u kojima osim prikaza zapanjujuće jednostavnosti Musashijeva 
pristupa mačevanju pisac daje naslutiti o kakvom je vrhunskome mačevalačkom geniju riječ (Jošikava 2: 216-42).

Musashijevu borbu s vlastitom životinjskom prirodom, odnosno neovladanim nagonima koji konstantno izranjaju kao prepreke na putu sablje, Yoshikawa izvanredno vješto i zorno oslikava upotrebom određene vrste sablje u dvobojima. Bez obzira na uvide (kensho) koji su ga preobrazili u „ljudsko biće“, Musashi se povremeno u dvobojima i dalje bori drvenom, a ne čeličnom sabljom što simbolizira opetovanu privremenu dominaciju degradirajućih životinjskih nagona i karakteristika. Kulminacija takve tranzitorne ekspresije „životinjskog“ Musashija događa se u dvoboju sa samurajima iz mačevalačke kuće Jošioka, kad Musashi na svirep i divljački način ubija glavu kuće Joshioka, dječaka Genjiroa:

'Genđiro! Nadam se da si tu i da nećeš biti onako neoprezan kao što su bili Seiđuro i Denšićiro. Vidim da si doveo dosta ljudi sa sobom, ali to je razumljivo zbog tvoje mladosti. Ja, Mijamoto Musaši, došao sam sâm. Spreman sam za borbu i izazivam vas, jednog po jednog ili u grupi' ... 'Bojim se!' vikao je mali Genđiro grleći stablo bora i pokušavajući da se popne na njega. 'Pomozite mi, u pomoć!' Genzaemon, njegov otac, skoči da zaštiti dečaka, ali je bilo suviše kasno. Musašijev mač je načinio dva duboka zareza na stablu bora, a s korom koja pade na zemlju, pade $i$ odsečena, sva krvava, dečakova glava. (Jošikava 2: 232)

Moralna osuda ovog čina ubrzo je došla od javnosti. lako Musashi inače nije mario za mišljenje drugih o vlastitim postupcima, u ovom slučaju i sam dvoji oko ispravnosti svog čina te si logički pokušava objasniti zbog čega je to učinio. Shvaća da mu njegova nemirna savjest ukazuje na nesigurnost $u$ ispravnost vlastita djelovanja, što indicira da je još daleko od dostizanja satorija:

Nije znao koliko je ljudi ubio onog dana ... Nije se čak jasno sećao ni kako je pobegao s onog mesta ... ni kako je uopšte došao u hram. Samo se dveju stvari sećao jasno, i one su ga morile i u snu: Genđirovog krika straha i izgleda njegovog obezglavljenog tela ... Taj čin se kao žbun pun trnja širio preko staze koju je izabrao za svoju budućnost, a budućnost mu se činila crna $i$ nevesela. (Jošikava 2: 249-50)

Kako navode Hanson i Mendius, razmišljanje o budućnosti, jednako kao i kopanje po prošlosti, u budizmu su poznati kao aktivnosti nepostojanog, tzv. „majmunskog“ uma (kapicitta) te predstavljaju 
uobičajeno stanje ljudskog uma koji je, uslijed diskurzivnog mišljenja, nestalan te neprestano podložan ometanju pažnje (145-49). To se, u biološkom kontekstu, objašnjava moždanom sposobnošću simuliranja događaja s ciljem prevencije opasnosti (procesi analiziranja prošlih neugodnih događaja i predviđanja budućih potencijalnih opasnosti) čime je naša mentalna aktivnost trenutno izvučena iz sadašnjosti i vraćena u prošlost, odnosno projicirana u budućnost. Smirivanje mentalne aktivnosti, odnosno utišavanje tog „unutarnjeg razgovora“ koji uporno osujećuje napredovanje k satoriju, jedan je od glavnih zadataka kontemplativne prakse u zenu (Jasutani-roši 19-20).

Također, slijeđenje tzv. „srednjeg puta“ u zen-budizmu predstavlja preporučeni životni stil. Yoshikawa daje dva svijetla primjera kako uvid u srednji put ne mora nužno biti povezan sa strogo uređenim pravilima svećeničkog života kakvi se primjerice prakticiraju u zen samostanima, već se može dogoditi spontano u različitim profanim životnim situacijama. Prvi opis govori o tome kako je boravak u kući s geishama Musashiju omogućio osvješćivanje vlastite pozicije u odnosu na slijeđenje srednjeg puta, dok drugi opis pokazuje njegov uvid u epizodi u kojoj slijedi učitelja zena Gudoa s ciljem da od njega dobije pouku o smislu života:

Do sada njegovo telo, njegova duša, sve je bilo kao led, hladna čvrsta masa neosetljiva na lepotu Meseca, mirise cveća, toplotu Sunca. Znao je veoma dobro i pre da estetski deo njegovog života nije uopšte bio bogat, ali je sada tek shvatio koliko je samoponištavanje bilo opasno za njega samog i činilo ga tvrdoglavim, uskih pogleda i ograničenim. Pre nekoliko godina Takuan mu je rekao da je njegova snaga divlja i da se uopšte ne razlikuje od snage bilo koje divlje životinje. I Nikkan ga je upozorio da je suviše jak, suviše da bi to bilo ljudski ... Dva dana koje je proveo u Ogiji pomogli su mu da se duh raširi mnogo dalje nego što je to do tada dozvoljavalo njegovo telo. (Jošikava 2: 162)

Kosa mu je bila kao gnezdo pacova i prošle su bile nedelje kako se nije okupao niti obrijao. Bio se zarekao da se neće uređivati dok mu učitelj ne kaže neophodnu reč. 'Koja sam ja budala!' odjednom viknu glasno. U trenutku mu je postalo jasno koliko je njegovo ponašanje detinjasto... Zar nije bilo moguće učiniti sve što je hteo u životu bez mučenja samoga sebe? Zašto je smisao morao da traži od učitelja zena kad mu je taj isti učitelj rekao da smisao mora da nađe sam.

(Jošikava 3: 312) 
Svoju povijesnu slavu Musashi stječe uvođenjem potpuno novog stila borbe sabljom. Naime, do tada su se samuraji uvijek borili dugom čeličnom sabljom, dok kratku nisu koristili u borbi. Musashi počinje koristiti i kratku sablju u dvobojima po principu „dvije ruke - dvije sablje“ što mu daje stratešku i tehničku prednost u odnosu na protivnike. U svojoj pisanoj ostavštini sâm Musashi svoju doktrinu naziva Nitenryu (Škola dvije sablje) gdje objašnjava kako „u borbi na život i smrt treba do maksimuma iskoristiti sve oružje“ te „da je velika šteta ako se umre sa jednim mačem neizvađenim iz korica“ (Musaši 20). Yoshikawa opisuje trenutak upotrebe druge sablje tijekom borbe s velikim brojem samuraja iz mačevalačke škole Joshioka kao nesvjestan čin, što u pravom smislu predstavlja još jedan kensho, koji Musashija transformira u mačevalačkog genija: „U jednom trenutku (koga ni sâm nije bio svestan) Musaši levom rukom izvuče kratki mač i poče da se bori sa obe ruke ... Sada je naglo prestao da se kreće i postao pravi gospodar situacije ... Njegove ruke postale su kao neka čelična vetrenjača koja mrvi sve ispred sebe opasnim krilima“ (Jošikava 2: 243). Ideju o upotrebi obje ruke u borbi Musashi dobije u razgovoru sa Soshidoom Baikenom, vrsnim majstorom u borbi kusarigamom ${ }^{[4]}$ :

Baiken je nastavio da priča ... pričao mu je o više načina bacanja kugle, o tome da lanac izgleda kao zmija i da ga treba upotrebljavati kao da čovek ima zmiju u ruci. Onda mu je odao tajnu kako se stvaraju optičke iluzije usaglašenim pokretima obe ruke i tako neprijatelj navodi da sam pobedi sebe. Musaši je bio očaran. Slušao je ne samo ušima i umom, već je sve ono što je govorio Baiken upijao celim bićem ... Lanac, srp. Dve ruke... dve ruke... Dok je slušao u glavi mu se lagano formirala misao da to što sada čuje može da primeni i u mačevanju ... To beše kao seme bačeno na plodnu zemlju. Seme koje će jednog dana, sasvim neočekivano, da nikne. (Jošikava 1: 372)

Ovdje Yoshikawa podcrtava kako puko intelektualiziranje ne dovodi do kreacije nečega novoga, već sve ostaje samo na razini ideje. Da bi njegova genijalost zaista zaživjela, bilo je potrebno da se Musashi nađe u borbi na život ili smrt, situaciji u kojoj je nužno funkcionirao probijajući intelektualnu barijeru, a što je istaknuto u prethodnom citatu kao djelovanje kojeg Musashi u tom trenutku uopće nije bio svjestan. Osvješćivanje samog čina upotrebe dviju sablji događa se tek dosta kasnije kad Musashi gleda kazališnu predstavu u kojoj mu pažnju privuku zvuci bubnjeva koji su cijeloj izvedbi davali ritam: 
'Pa, da, dve palice kao dva mača. Kad se dobro usklade pokreti, dve palice daju jedan jedinstveni zvuk. Isti zakon važi za sve. I za mačeve i za palice.' - Sada, dok je razmišljao o tome, sve mu se činilo normalno i prirodno ... Način borbe $s$ dva mača trebalo je da bude sličan tome, svestan, ali u isto vreme automatski, kao refleks, potpuno oslobođen smetnji koje postoje u običnom svesnom aktu ... Bubnjar je svestan onoga što čini levom i desnom rukom, ali u isto vreme i nesvestan svega toga. Pred njegovim očima postojala je budistička sfera slobodne interpretacije i Musaši je osetio nešto što bi moglo da se nazove prosvetljenjem. (Jošikava 3: 217-19)

Ova situacija osvješćivanja, odnosno susret i sjedinjenje intuitivnoga i diskurzivnoga, bez sumnje predstavlja još jedan u nizu kenshoa koje Musashi doživljava na putu sablje. Evolucijski princip, metaforički prikazan upotrebom dviju sablji, dovodi Musashija u stanje duha koje je analogno ničeanskom nadčovjeku - riječ je o slobodnom, uzvišenom duhu koji, nesputan moralnim ograničenjima, nadrasta okvire vrijednosti koji su ga priječili u kreaciji novih. Ničeanski nadčovjek također pokazuje niz drugih istovjetnih karakteristika prosvijetljenom (Buddhi), po čemu ih neki zapadnjački filozofi percipiraju nedistinktivnima (Priest 78-106). Ipak, drugačija gledišta, poput onoga koje iznosi i argumentira Masao Abe, ukazuju da, za razliku od zenovskog ništavila ili praznine $(\mathrm{ku})$ u kojoj diskriminirajući um nestaje, pokretačka sila ničeanskog nadčovjeka, volja za moć, ne predstavlja totipotentnu prazninu već „nešto“ što u svojoj osnovi upravo jest diskriminirajući um ne-slobodan od objektivizacije svijeta. Stoga, Abe zaključuje da ničeanski nadčovjek mora postati „istinskim čovjekom“ da bi se mogao smatrati probuđenim, odnosno Buddhom (Abe 68).

\subsection{Musašijev satori - iskustvo čovjeka povrh nadčovjeka}

Yoshikawa uvodi različite likove u fabulu tako da gotovo svaki lik s kojim Musashi dolazi u interakciju simbolizira neku od manjih ili većih zapreka na njegovu putu prosvjetljenja. Ipak, najveću pozornost privlači lik još jednoga mačevalačkog genija, Sasakija Kojiroa. Vještina koju Kojiro demonstrira u rukovanju sabljom indicira kako je on definitivno dosegao razinu genijalnosti i da je, kao takav, jedini „pravi“ i dostojan protivnik Musashiju: 
Kad je malo odrastao, počeo je već da o sebi govori kao o geniju. Bilo je tu mnogo samohvalisanja, ali i Đisai i Ittosai su shvatili da u tom hvalisanju ima i dosta istine ... To je stvorilo od njega individualca i skoro da je bio u pravu kad je tvrdio da stvara sopstveni stil. Ljudi iz susedstva smatrali su ga nekom vrstom čarobnjaka, i u tome beše isto toliko hvale kao i straha. (Jošikava 2:

lako Kojiroovo odbijanje diplome koju mu je namijenio njegov učitelj mačevanja, kako ga ista ne bi „okovala“ i spriječila u daljnjem napretku na putu sablje, može na prvi pogled izgledati kao potpuna sloboda i odvojenost od materijalnih vrijednosti i potrebe za ovosvjetovnom časti, ovdje je riječ o potpuno pogrešnom motivu - prevelikom egoizmu, koji Kojiroa ne napušta do samog kraja: „'Diploma mi nije potrebna. Ja želim više od toga' ... 'Ja nameravam da stvorim stil Ganrju i uopšte više ne mislim o stilu Ćuđo. Uskoro će ceo Japan čuti o imenu Ganrju' ... U Kođirovim rečima ne beše ni trunke skromnosti. Ni trunke stida. Govorio je ono što ljudi obično zadržavaju za sebe“ (Jošikava 2: 176). Osim enormnog ega, Kojiro konstantno eksprimira niz loših osobina poput podlosti, zluradosti i svireposti, što pokazuje da se radi o čovjeku upitnog morala (Jošikava 3: 7475).

Kratki susreti Kojiroa i Musashija koji se događaju tijekom fabule romana nagovješćuju da se radi o ljudima koji će prije ili poslije završiti u dvoboju na život i smrt: „Njihove oči se susretoše sevajući kao da se dve divlje životinje, zavađene na život i smrt, suočavaju jedna s drugom. Posmatrali su se kao da pokušavaju da snagu svog karaktera i karaktera onog drugog isprobaju u tom sevanju pogleda“" (Jošikava 2: 176). Usprkos naglašavanju iskonske, životinjske prirode pri odmjeravanju protivnika, Yoshikawa u potpuno drugačijem svjetlu opisuje Musashija nakon što ga Kojiro napokon izazove na dvoboj. Kao prvo, Musashi kasni pri polasku na dvoboj, no to ga ne sprečava da domaćinima naslika sliku. Upravo kroz taj kreativan čin Musashi uzima dovoljno vremena da se sabere i očisti um, čime se izvrsno priprema za neizvjesnu borbu: „Duh mu je bio potpuno čist. Sve misli ostavio je u tušu koji je stavio na hartiju. Kretao je na Funašimu kao na običan put, ne razmišljajući čak ni da li će se vratiti“ (Jošikava 3: 369-71). Yoshikawa manirom vrsnog poznavatelja filozofije zen-budizma detaljno opisuje stanje Musashijeva duha koji je bio potpuno smiren i harmoniziran te nesvjesno fokusiran na predstojeći dvoboj: 
Sasuke je počeo da se znoji ... Nije mogao da shvati da neko može tako mirno da ide u bitku na život i smrt... 'Ovaj je miran kao beli oblačić na nebu', pomisli on ... Musaši, međutim, nije uopšte skrivao osećanja ... samo je, dok je rukom provlačio kroz vodu pomišljao da u stvari čovekov život počinje tek kad se oslobodi nepostojane forme kakva je telo ... Kao da je svaki deo njegovog tela zaboravio na samog sebe i kao da je svaki njegov delić smatrao da ne postoji. (Jošikava 3: 367)

Opis odgovara pojmu zenovskoga nepokretnog uma (fudoshin), koji Vertovšek pojašnjava tako da je osoba koja napreduje na putu neke od borilačkih vještina sve manje „slika o sebi koja nešto vježba, a sve više ono-što-vježba“ (116). Upravo ovakvo poimanje sebe, odnosno svog ,ja“, koje je oslobođeno svakog objektiviziranja, a time i parcijalnih uvida, neophodno je za konačnu spoznaju jer se mora uvidjeti na apsolutno subjektivan način da bi se očitovalo kao praznina (ku, sunyata). Tek tada će, uslijed poistovjećivanja subjekta i objekta, um i tijelo moći savršeno djelovati kao cjelina (Suzuki i From 50). Dakle, kako navodi Stojanović, ulazak u satori podrazumijeva intuitivno sagledavanje stvari (64), što je u suprotnosti s analitičkim i logičkim djelovanjem/ustrojem diskurzivnog uma.

\subsection{Povratak drvenoj sablji odnosno povratak „,k sebi“}

Musashijevo konačno postizanje satorija dogodilo se u čamcu netom prije iskrcavanja na kopno pri čemu Yoshikawin opis samog čina djeluje gotovo naivno: „Pomerivši kratki mač na sredinu pojasa, on izvadi dugi i spusti na dno čamca, prekrivši ga tankom asurom. U desnoj ruci ostade mu samo drveni mač koji je bio izdeljao od komada starog vesla" (Jošikava 3: 380-81). Vrlo često autori ne prave razliku između pojmova kensho i satori, jer oba termina označavaju stanje uma u kojem dolazi do uvida u pravu, istinsku (buddhinsku) prirodu stvari. Ipak, dogovorno, pod pojmom kensho podrazumijevaju se početni uvidi koji prethode satoriju, a koji nemaju toliko jaku moć transformacije kao sâm satori (Austin 10). Za razliku od prethodnih kenshoa opisanih u romanu, na koje Yoshikawa direktno ukazuje kao na transformirajuće uvide Musashijeve svjesnosti, pojašnjavajući in čitatelju, u slučaju Musashijeva konačnog dosega satorija, Yoshikawa se praktički uopće ne osvrće na taj događaj. Ova Yoshikawina šutnja, potpuno ignoriranje i odbijanje verbalizacije daje čvrsti argument da se zapravo radi o istinskom satoriju. Naime, „ako se jedan 
doživljaj može mentalno ili emocionalno opisati, tada to nije pravi satori“ (Wood 157). Nakon opisa Musashijeva satorija, Yoshikawa praktički odmah prelazi na detaljan opis dvoboja s Kojiroom, što istovremeno predstavlja vrhunac i rasplet fabule:

Kad vide nešto crvenkasto što, vrteći se, proleće kroz vazduh, Ganrju pomisli da je uspeo da jednim udarcem Musašiju odseče glavu i preko lica mu prelete osmeh. Ali, samo delić sekunde kasnije, lobanja mu se raspršte kao kamenčić pod udarcem teškog čekića. Razbio ju je, prosto smrvio, jedan jedini udarac Musašijevog drvenog sablje (Jošikava 3: 384).

Dodatnu potvrdu da se prethodno radilo o istinskom satoriju Yoshikawa daje u opisu Musashijeva ponašanja netom nakon završetka dvoboja: „Bitka je bila završena i bilo je vreme da se krene ... Poklonivši se duboko, do zemlje, on se okrete i u nekoliko skokova stiže do čamca ... Čamac se otisnu na more i ništa ga ne uznemiri“ (Jošikava 3: 386). Ovaj opis neodoljivo podsjeća na pouku o prosvjetljenju koja je opisana u jednoj predaji, a prilikom koje je Bodhisattwa u liku starca podario prosvjetljenje tragaocu u liku zen redovnika (Gorjanski 14-15). U priči, zen redovnik, penjući se uz planinu s namjerom traganja za prosvjetljenjem, sretne starca s naramkom drva na leđima koji se spuštao s planine i zapita ga zna li nešto o prosvjetljenju. Starac ispusti naramak drva na zemlju, što trenutno prouzroči redovnikovo prosvjetljenje: „Kako jednostavno! Samo pustiti i ne težiti ničemu!" Međutim, redovniku se odmah nametnulo pitanje što dalje, na što se starac sagne, podigne naramak i zaputi dalje niz planinu. Pouka koju nam ova priča daje, govori kako prosvjetljenje zapravo nije "ništa posebno“ (Austin 10-11) i da se transformacija svjesnosti uzrokovana satorijem treba manifestirati jednostavno kao kontinuirano svakodnevno „bivanje“. Naravno, kako navodi Yoshigasaki, život nakon prosvjetljenja podrazumijeva totalnu percepciju (za razliku od parcijalne percepcije koja je posljedica misli, tj. djelovanja diskurzivnog uma) iz koje nastaju novi koncepti karakteristični za bivanje nakon prosvjetljenja (77-78). Ti novi koncepti života nakon prosvjetljenja „stvaraju novu percepciju svijeta, a nova percepcija zauzvrat stvara novi koncept“ (Yoshigasaki 59). Nadalje, „novi koncept stvara novu koncepciju“ iz čega proizlazi da je „život nakon prosvjetljenja ... evolucija između percepcije i koncepcije“ (Yoshigasaki 78).

\section{Zaključak}


U remek-djelu japanske književnosti, Eiji Yoshikawa fikcionalizira život jednog od najpoznatijih japanskih mačevalaca, Miyamota Musashija. U djelu prikazuje njegovo sazrijevanje i duhovni razvoj od neuljuđenog mladića kojeg kontroliraju životinjski nagoni do mačevalačkog genija potpuno prožetog svojom buddhinskom prirodom. Pri tome Yoshikava metaforički prikazuje Musashijev napredak na putu prosvjetljenja upotrebom različitih tipova sablji koje simboliziraju njegovu transformaciju. Musashi se isprva koristi drvenom sabljom (bokken) koji predstavlja njegovu sirovu, životinjsku prirodu, no istovremeno je i prvi korak k prosvjetljenju. Posezanje za dugačkom, čeličnom sabljom (katana) i ovladavanjem njome u borbi sugerira Musashijev drugi stupanj preobrazbe u ljudsko biće spremno napredovati na putu. Treći korak u transformaciji zbiva se kada protagonist mijenja paradigmu mačevanja i počinje se boriti s dvije sablje. Tim se podvigom Musashi uzdiže iznad ostalih protivnika zrcaleći odlike nadčovjeka u svojoj produhovljenosti i superiornosti. Zaključno, korjenitost i dubina Musashijeva uvida prouzročila je njegovu konačnu transformaciju iz ničeanskog nadčovjeka u onoga što Abe naziva istinskim čovjekom. Zapravo, radi se o slobodno bivajućem rinzaijevskom „čovjeku bez položaja“ (Suzuki i From 56). Istinski vrhunac radnje i transformacije protagonista do te je mjere suptilno naznačen, da čitatelj nevješt istočnjačkoj religiji i tradiciji tu epizodu lako može previdjeti. Trenutak kada Musashi, gotovo nesvjesno, odlaže katanu i poseže za drvenom sabljom koju je izradio na putu u dvoboj događa se netom prije dvoboja i predstavlja trenutak njegova konačnog probuđenja (satori). Tim je činom Musashi pristigao na svoje konačno odredište i vratio se svojoj izvornoj buddhinskoj prirodi (bitku), odnosno, „k sebi“ (Gorjanski III).

\section{Bibliografija}

Abe, Masao. „Zen i Niče.“ Zen danas, urednik Dušan Pajin, Dečje novine, 1989. str. 59-70.

Austin, James H. Zen-Brain Reflections. The MIT Press, 2006.

Bodhi, Bhikkhu. The Noble Eightfold Path. Buddhist Publication Society, 2010.

Frederik, Luj, i Mišel Random. Japan. Preveo Dragoslav Andrić, Jugoslovenska revija, 1988.

Gorjanski, Dražen. Zen priče. Karate klub Osijek, 1997.

Gruden, Vladimir. Vježbom do sreće. Autogeni trening. Liber, 1985. 
Hanson, Rick, i Richard Mendius. Budin mozak. Praktična neuroznanost sreće, ljubavi i mudrosti. V.B.Z. d.o.o., 2014.

Jasutani-roši. „Zen meditacija - smisao i praksa“. Zen danas, uredio Dušan Pajin, Dečje novine, 1989, str. 18-41.

Jošikava, Eiđi. Mijamoto Musaši. Preveo D. Milenković, sv. 1-3, Dečje novine, 1988.

Milenković, Dragan. Musaši i njegovo doba. Pet krugova, autor Mijamoto Musaši, Gornji Milanovac, 1988, str. 133-91.

Musaši, Mijamoto. Pet krugova. Preveo Dragan Milenković, Dečje novine, 1988.

Nietzsche, Fridrich. Tako je govorio Zaratustra. Preveo Mario Kopić, Večernji posebni proizvodi, 2009.

Nitobe, Inazo. Bushido: kodeks samuraja. Preveo Nebojša Buđanovac, Planetopija, 2007.

Peić, Matko. Pristup likovnom djelu. Školska knjiga, 1968.

Priest, Stephen. Nietzsche and Zen. Michaelmas, 2007.

Roberts, Jeremy. Japanese Mythology A to Z. Chelsea House, 2010.

Stori, Ričard. Život samuraja. Prevela Snežana Smiljković, Jugoslovenska revija, 1987.

Stojanović, Siniša. Teorija i praksa zen budizma. Arion, 1988.

Sumedo, Ađan. Četiri plemenite istine. Preveo Branislav Kovačević, Theravada budističko društvo "Srednji put“, 2007.

Suzuki, Daisetz Teitaro. Zen i samuraji. Preveo Nenad Vertovšek, Diorama, 2005.

Suzuki, Daisetz Teitaro, i Erih From. Zen budizam i psihoanaliza. Preveo Branko Vučićević, Nolit, 1977.

Ščerbatski, Fjodor. Koncepcija buddhističke nirvāne. Preveo Goran Kardaš, Demetra, 2005.

Vertovšek, Nenad. „Filozofija zena i borilačke vještine. Od svjesnosti do nepokretnog uma.“

Metodički ogledi, vol. 19, no. 1, prosinac 2012, str. 113 - 39.

Wood, Ernst. Rječnik zena. Preveo Nenad Vertovšek, Biblioteka Do, 2008. 
Yoshigasaki, Kenjiro. Unutarnje putovanje stranca. Preveo Davor Kudrna, Zona Vitae, 2002. 
[1] bushi - vojnik, ratnik.

[2] U slučaju drvenog mača, drvo predstavlja ontologijsku karakteristiku stvarnosti, odnosno stvar u svom izvornom obliku (neosobnu te bez predodžbi i tumačenja naziva i oblika), tj. stvar samu po sebi koja predstavlja beskonačan skup mogućnosti.

[3] U svom djelu, Tako je govorio Zaratustra, Nietzsche navodi tri preobrazbe duha: iz duha u devu, iz deve u lava i iz lava u dijete. Deva na sebi nosi teret čvrstog svijeta vrijednosti kojemu je podčinjena, baš kao što je i Musashi podčinjen svojim životinjskim nagonima. U pustinji se deva preobražava u lava i odbacuje teret, spoznaje sebe te je tako oslobođen kompetentan nositi se s predstojećim izazovima. U romanu, Musashi u tom trenutku odbacuje svoje staro ime i identitet te započinje novi život kao ratnik.

[4] kusarigama - tradicionalno japansko oružje koje se sastojalo od dugog lanca koji je na jednom kraju imao sječivo, a na drugom uteg (najčešće kuglu).

\section{c) (1) $\odot \odot$}

Creative Commons Attribution-NonCommercial-NoDerivatives 4.0 International License 